\title{
Formulation of Functional Multigrain Bread and Evaluation of their Health Potential
}

\author{
Shakshi Sharma*, Nivedita Sharma, Ranjana Sharma and Shweta Handa \\ Microbiology Research Laboratory, Department of Basic Sciences, Dr Y S Parmar University \\ of Horticulture and Forestry, Nauni, Solan-173230, HP, India \\ *Corresponding author
}

\section{A B S T R A C T}

\begin{tabular}{|l|}
\hline Ke y w o r d s \\
Kodo millet, Wheat, \\
$\begin{array}{l}\text { Multigrain bread, } \\
\text { Nutritional evaluation, } \\
\text { Sensorial study }\end{array}$ \\
\hline Article Info \\
\hline $\begin{array}{l}\text { Accepted: } \\
\text { 28 April } 2018 \\
\text { Available Online: } \\
\text { 10 July } 2018\end{array}$ \\
\hline
\end{tabular}

\section{Introduction}

Bread has been regarded for centuries as one of the most popular and appealing food product both because of its relative high nutritional value and its unique sensory characteristics (texture, taste, and flavor). In recent years, with the increasing urbanization as well as the advancement in baking technology and changing food habits, the bakery food products such as bread are now becoming popular in urban and semi urban areas of the most developing countries (Aggarwal, 1990). The objective of supplementing alternative ingredients in bread formulation is to improve the nutritional value of wheat flour particularly proteins, minerals, vitamins and dietary fibre (Hallen et al., 2004). One of the most important cultivated species includes Kodo millet (Paspalum scrobiculatum) which is grown primarily in India. It is a very hardy crop that is drought tolerant and can survive on marginal soils where other crops may not survive, and can supply 450-900 kg of grains per hectare. Thus millets have great potential for being utilized in different food systems by virtue of their nutritional quality and economic importance. However, Recognition of the beneficial nutritional attributes of this crop grains due to the complementarily of their essential amino acids with those of wheat has led to world- 
wide attempts to fortify traditional wheat bakery products, such as bread with locally grown unexploited grains (Patel and Rao,1995) Several studies about the influence of the addition of cereal flours such as sorghum, maize and barely, as well as rich lysine legumes, on the physicochemical properties of bread dough and its final products quality have been reported in the last three decades. (Gayle et al., 1986; Shefali and Sudesh, 2001; McWatter et al., 2004).

Formulation of composite flour is vital for development of value added products with optimal functionality (Rehman et al., 2007). A variety of wheat flour substitutes such as soy or defatted soy flour (Junqueira et al., 2008), defatted wheat germ (Arshad et al., 2007), flax seed (Koca and Anil, 2000), sunflower seed (Skrbic and Filipcey, 2008), chem- pedak seed flour (Mardiana, 2008), and rice bran (Sharpe and kitchen, 1990; Sharma and Chauhan, 2002) have been tried in bakery formulation with varying success.

Therefore there is an enormous scope growing in this crop to explore the technological possibilities of its utilization in food industry for the preparation of various food products. However, an increasing number of individuals are suffering from celiac disease (CD), the life-long intolerance to the gluten fraction of wheat, rye and barley. In particular, celiac patients are intolerant to some cereal prolamins containing specific toxic oligopeptide sequences. The gliadin fraction of wheat, secalins of rye, hordeins of barley, and possibly avenins of oats are involved in the CD mechanism. There is an enormous scope of exploring the technological possibilities of the utilization of kodo millets in food industry for the preparation of various healthy food products (Sharma et al., 2017). The aim of this work was to evaluate the nutritional pattern of gluten free breads regarding their chemical composition in order to determine their contribution to the daily intake of nutrients. An attempt has been made to formulate the product which is gluten free and highly nutritious in nature.

\section{Materials and Methods}

\section{Collection and processing of grain sample}

Kodo millet grains were collected from different districts of Himachal Pradesh i.e. Kangra, Mandi and Hamirpur and brought to the laboratory. All samples were segregated, cleaned and stored in air tight containers. Malting was done by germination of kodo millet seeds at $25-30^{\circ} \mathrm{C}$ under dark place. The pooled grains (native and malted millet grains) were grinded in a mixer to get whole flour of $1.0 \mathrm{~mm}$ sieve size and used for the preparation of multigrain bread.

\section{Phytochemical analysis of millet grains}

The aluminium chloride method was used for the determination of the total flavonoid content of the sample (Madaan et al., 2012). The concentrations of flavonoid in the test samples was calculated from the calibration plot and expressed as mg quercetin equivalent /g of sample. DPPH (2, 2-diphenyl-1picrylhydrazyl) was used as a source of free radical (Brand et al., 1995). The amount of total phenols in the sample was determined with the Folin-Ciocalteau reagent according to method of Bray and Thorpe (1954).

\section{Formulation of multigrain bread}

\section{Composite flour}

Multigrain flour was prepared by combining wheat and kodo millet in different ratios i.e. 30:70, 40:60, 50:50, 60:40 and 70:30 (wheat: kodo millet). Among these, 50:50 ratio of wheat and kodo millet was standardized for further studies. 


\section{Preparation of dough and fermentation}

\section{Ingredients}

Millet flour: $50 \mathrm{~g}$

Wheat flour: $50 \mathrm{~g}$

Yeast: $1 \mathrm{mg}$

Sugar: $10 \mathrm{~g}$

Salt: $5 \mathrm{~g}$

Oil: $10 \mathrm{ml}$

\section{Recipe}

\section{Nutritional evaluation of multigrain bread}

Proteins, crude fats, carbohydrates, crude fibers and antioxidants were measured as per different standard methods (Ranganna, 1990; Folch, 1957; Sadasivam and Manickam, 1992; Brand et al., 1995).

\section{Sensorial Evaluation}

Nine point hedonic scale method as given by Amerine et al., (1965) was followed for conducting the sensory evaluation of multigrain bread. The panel of 10 judges was selected to evaluate multigrain bread.

\section{Statistical analysis}

Data pertaining to the physicochemical attributes was analyzed by Completely Randomized Design (CRD) and sensorial evaluation of multigrain bread was analyzed by Randomized Block Design (RBD) as described by Mahony (1985).

\section{Results and Discussion}

Multigrain bread of kodo millet was prepared by mixing wheat and kodo millet in different ratios. Standardization of different ratios of wheat: kodo millet i.e. 30: 70, 40: 60, 50: 50, 60: 40, 70:30 has been done. Baker's yeast i.e. Saccharomyces cerevisae was added at the rate $10^{8} \mathrm{cfu} / \mathrm{ml}$. The best ratio was selected on the basis of its physical attributes and 50:50 was finally selected shown Table 1 . It has been shown in the results that addition of high level of kodo millet in the wheat flour will lead in decrease in softness and appearance of the bread as shown in Plate 1. Similar studies had shown the same effect, where, Mathews et al., (1970) mentioned that substituting high levels of sunflower flour resulted in deterioration of crumb colour and texture of the bread.

Table 2 represents the comparison of multigrain bread (kodo millet: wheat) with the commercial, wheat bread and the multigrain bread had been found to be rich in vital nutrients i.e. proteins, fats and overall contents as compared to the wheat bread. When nutrient facts were compared with commercial wheat bread, it has been observed that kodo millet multigrain bread had much higher proteins fiber and antioxidants as compared to commercial wheat bread. Thus, proving it to be a better product for consumers. Clopicka $e t$ al., 2012 examined the phenolic contents of different kinds of flour and breads, and were expressed as mg gallic acid per gram of dry weight. Buckwheat flour had the highest phenolic content $(7.25-0.23 \mathrm{mg} / \mathrm{g})$ and the next one was wheat $(6.96-0.11 \mathrm{mg} / \mathrm{g} \mathrm{dw})$. Amaranth and quinoa flour had the lowest phenolic content (2.71-0.1 mg/g and 2.8- 0.1 $\mathrm{mg} / \mathrm{g}$, respectively) and the differences between them and the former two were statistically significant.

Karwe et al., (2003) observed lower content of total phenolics in buckwheat white, raw flour, but higher content of total phenolics of buckwheat dark, raw flour in comparison with phenolic content in our buckwheat flour. Consistently with the above results, the content of phenols in breads was highest in breads baked with $30 \mathrm{~g} / 100 \mathrm{~g}$ addition of buckwheat flour $(2.65-0.10 \mathrm{mg} / \mathrm{g})$. 
Table.1 Standardization of different ratio of wheat and kodo millet based on physical attributes

\begin{tabular}{|l|l|l|l|l|l|l|l|}
\hline $\begin{array}{l}\text { Sr. } \\
\text { no. }\end{array}$ & $\begin{array}{c}\text { Ratios (wheat: } \\
\text { kodo millet) }\end{array}$ & Colour & Texture & Taste & Appearance & Softness & Mean \\
\hline $\mathbf{1}$ & $30: 70$ & 2 & 1 & 2 & 1 & 1 & 1.4 \\
\hline $\mathbf{2}$ & $40: 60$ & 2 & 1 & 2 & 1 & 2 & 1.6 \\
\hline $\mathbf{3}$ & $50: 50$ & 3 & 2 & 3 & 2 & 3 & 2.6 \\
\hline $\mathbf{4}$ & $60: 40$ & 1 & 2 & 3 & 2 & 2 & 2.0 \\
\hline $\mathbf{5}$ & $70: 30$ & 1 & 2 & 2 & 2 & 2 & 1.8 \\
\hline
\end{tabular}

1: poor

2: fair

3: good

Table.2 Nutritional chart of multigrain bread (kodo millet: wheat) and wheat bread

\begin{tabular}{|l|c|c|c|}
\hline \multirow{2}{*}{ Parameters } & \multicolumn{2}{|c|}{ Nutritional facts per $\mathbf{1 0 0}$ g } & t-test \\
\hline Multigrain bread & $\begin{array}{c}\text { Wheat or whole bread* } \\
\text { (commercial) }\end{array}$ & \\
\hline Proteins $(\mathbf{g})$ & 9.7 & 3.0 & 165.72 \\
\hline Carbohydrates $(\mathbf{m g} / \mathbf{g})$ & 80 & 144 & 9.89 \\
\hline Crude fibers $(\mathbf{g})$ & 21 & - & 75.7 \\
\hline Fats $(\mathbf{g})$ & 1.5 & 1.0 & 15.3 \\
\hline Total phenols $(\mathbf{m g} / \mathbf{g})$ & 6.13 & - & 22.07 \\
\hline Flavonoids $(\boldsymbol{\mu g} / \mathbf{m l})$ & 2.2 & - & 39.66 \\
\hline
\end{tabular}

*: calorieking.com

Plate.1 Multigrain bread [Wheat: Kodo millet (50: 50)]
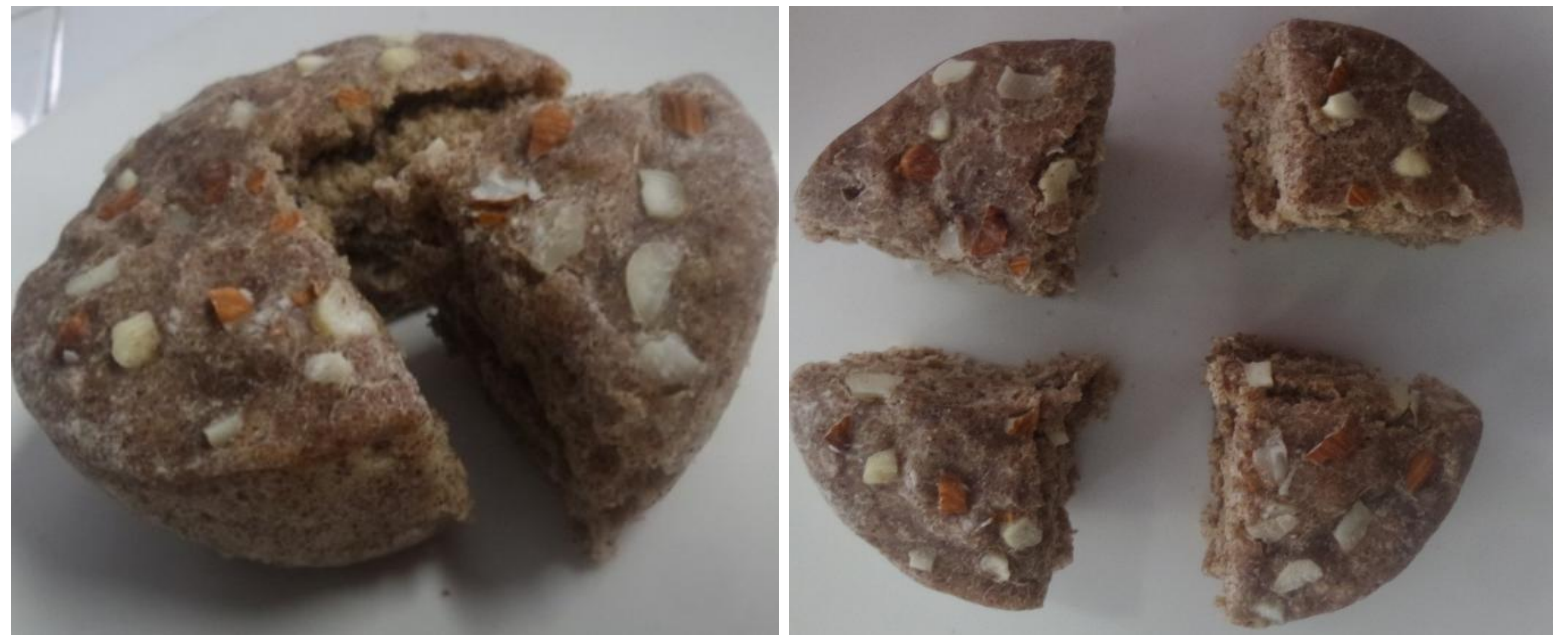
Fig.1 Sensorial evaluation of multi grain bread

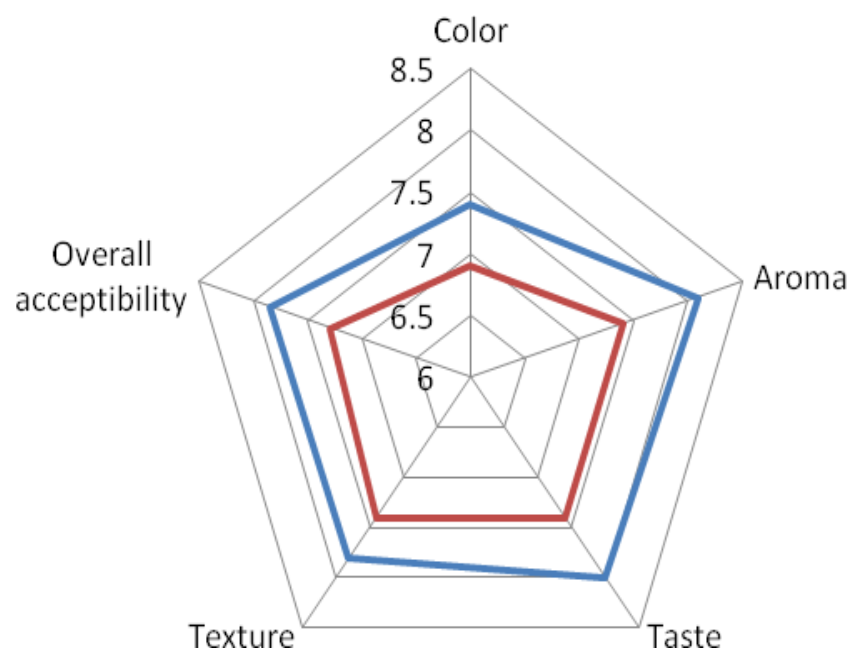

50:50:00

$-30: 70$

Flow chart for preparation of multigrain bread

Multigrain flour

[50:50 (wheat: kodo millet)]

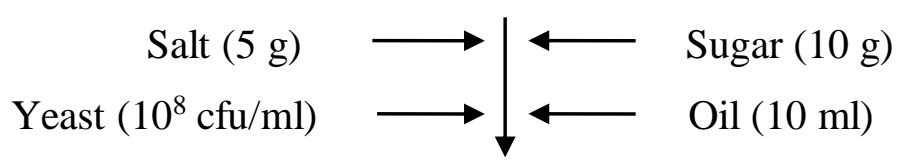

Knead (water, $100 \mathrm{ml}$ )

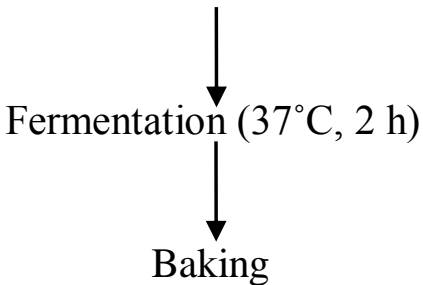

$\left(450^{\circ} \mathrm{F}\right.$ for $\left.30 \mathrm{~min}\right)$

The sensory evaluation showed maximum acceptability of Set A compared to control as it scored 8.1 out of 10 .

The results showed a significant effect of different treatments on sensory attributes in gluten free bread as shown in Fig1. The novel functionally formulated multigrain bread have been shown to have high nutritional value along with other exceptional health benefits due to high antioxidants as compared to white bread as supported by sensorial evaluation thus fulfilling the quantitative traits or attributes proving its high market potential. 


\section{Acknowledgements}

The authors are very thankful to the Department of Enviornment, Science and Technology, H. P. Govt. for funding this study.

\section{References}

Agrawal SR (1990) Prospects for small-scale biscuit industry in the nineties. Indian Food Industry 9 19-21

Amerine M A, Pangborn R M and Rossler E B (1965) Principles of sensory evaluation of food. Academic Press, New York, $254 \mathrm{p}$.

AOAC, Official methods of analysis of association of official analytical chemists, (Association of Official Analytical Chemists, Arlington, Virginia, USA), 2007.

Arshad M, Anjum F and Zahoor T (2007) Nutritional Assess- ment of Cookies Supplemented with Deflated Wheat Germ Food Chemistry 102 123- 128.

Brand W W, Cuvelier M E and Berset C (1995) Use of free radical method to evaluate antioxidant activity Food $S c i$ Techno 28 25-30

Bray H G and Thorpe W V (1954) Analysis of phenolic compounds of interest in metabolism, Methods Biochem Analysis 52 1-27.

Folch J, Lees M and Sloane-Stanley G (1957) A simple method for isolation and purification of total lipids from animal tissues. J Bio Chem 226 497-509

Gayle P E, Knight E M, Adkins J S and Harland B F (1986) Nutritional and organoleptic evaluation of wheat breads supplemented with pigeon pea flour Cereal Chemistry 63 136-138.

Hallen E, Ibsnoglu S and Anisworth P (2004) Effect of Fer- mented/Germinated Cowpea Flour Addition on the Rheo- logical and Baking Properties of Wheat Flour Food En-gineering 63 177-184.

Hedge J E and Hofreiter B T (1962) In: Methods in carbohydrate chemistry, (Academic press, New York) pp. 10-12 Junqueira RM, Cocato ML, Colli C and Castro LA (2008) Synergisms between Lipoxygenase-Active Soybean Flour and Ascorbic Acid on Rheology and Bread Quality Journal of Science, Food and Agriculture 87 1172-1175

Koca F and Anil M (2000) Effect of Flaxseed and Wheat Flour Blends on Dough Rheology and Bread Quality Journal of Science, Food and Agriculture, 87 1172-1175

Madaan R, Bansal G, Kumar S and Sharma A (2012) Estimation of total phenols and flavonoids in extract of Acta easpicata roots and antioxidant studies, Indian $J$ Pharm Sci 73 666-669

Mahony M O (1985) Sensory evaluation of food: statistical methods and procedures. Marcel Dekker Inc., New York, $132 \mathrm{p}$.

Mardiana B A Z (2008) Effects of Partial Substitution of Wheat Flour with Chempedak (Artocarpus integer) Seed Flour on the Physico-Chemical, Organoleptic and Micro- biological Attributes of the Bread," M.Sc. Thesis, University of Sains, Malaysia

Mathews T J, Hamilton B E Mean age of mother. 1970-2000. National vital statistics reports; vol 51 no 1 . Hyattsville, MD; National Center for health Statistics.

McWatter K H, Philips R D, Walker S L, McCullough S E, Mensah-Wilmot Y and Saalia F K (2004) Baking performance and acceptability of raw and extruded cowpea flour breads Journal of food quality 27 337-351

Patel M M and Rao G V (1995) Effect of Untreated, Roasted and Germinated Black Gram (Phaseolus mungo) Flours 
on the Physicochemical and Biscuit (Cookie) Making Characteristics of Soft Wheat Flour. Journal of cereal science 22 285-291

Ranganna S (1997)Handbook of analysis and quality control for fruit and vegetable products, (Tata McGraw Hill Publishing Comapany Ltd., New Delhi, India), $1109 \mathrm{p}$.

Rehman S, Paterson A, Hussain S, Murtaza M A and Mehmood S (2007) Influence of Partial Substitution of Wheat Flour with Vetch (Lathyrus sativus L) Flour on Quality Characteristics of Doughnuts Leben Smitted Wissen- chaffund Technologies 40 73-82

Sadasivam S and Manickam A (1992) Biochemical methods for agricultural science, (Willey eastern limited, New Delhi), 10-11.

Sharma H R and Chauhan G S (2002) Effect of Stabilized Rice Bran-Fenugreek Blends on the Quality of Breads and
Cookies Journal of Food Science and Nutrition 39 225-233.

Sharma S, Sharma N, Handa S and Pathania S (2017) Evaluation of health potential of nutritionally enriched Kodo millet (Eleusine coracana) grown in Himachal Pradesh, India. Food Chemistry 214 $162-168$

Sharpe C Q and Kitchen K J (1990) Using Rice Bran in Yeast Bread in a Home Baker Cereal Foods World 35 10211028.

Shefali D and Sudesh J (2001) Organoleptic and nutritional evaluation of wheat breads supplemented with soybean and barley flour Food Chemistry 77 479488

Skrbic B and Filipcev B (2008) Nutritional and Sensory Eval- uation of Wheat Breads Supplemented with Oleic-Rich Flower Seed Food Chemistry 180 119129.

\section{How to cite this article:}

Shakshi Sharma, Nivedita Sharma, Ranjana Sharma and Shweta Handa. 2018. Formulation of Functional Multigrain Bread and Evaluation of Their Health Potential. Int.J.Curr.Microbiol.App.Sci. 7(07): 4120-4126. doi: https://doi.org/10.20546/ijcmas.2018.707.480 